\title{
Linkages between Electricity Consumption and Economic Growth: Evidences from South Asian Economies ${ }^{1}$
}

Prof. Dr. Kamal Raj Dhungel

\begin{abstract}
Researchers have options to choose the model to assess the exact relationship between electricity consumption and economic activity. One can use the model based either in demand side or in supply side. This paper considers electricity as an essential factor of production. Thus it uses the demand side model to reexamine the association and determine the causality between the variables electricity consumption (EC) and gross domestic product (GDP) of five south Asian countries during the period 2000-2011 AD. A panel unit root test, panel co-integration test are used to determine the long run equilibrium. Fully modified ordinary least square method was applied to estimate the panel electricity elasticity coefficient. Granger causality based on Vector Auto Regression model was then applied to determine the direction of causality. The data are found stationary at first difference but are found non-stationary at their level. Co-integration test confirmed the long run relationship or equilibrium between the variables EC and GDP. The electricity elasticity coefficient (EEC) is 1.31. It reveals that a $1 \%$ increase in electricity consumption would lead to increase the GDP by $1.31 \%$ indicating a highly responsive electricity demand. In the spontaneous process of economic development of south Asian countries, there is a significant impact of EC on GDP. The value of EEC is self-spoken. A large change in GDP would be expected from a small change in EC. It has a big implication of bringing rapid economic progress within a short span of time and any shortage of electric energy would retard economic progress. Electricity consumption is found to Granger cause GDP. This unidirectional causality running from electricity consumption to GDP has important policy implication-electricity consumption leads economic growth which has two policy implications. One, reduction of electricity consumption through bringing domestic energy prices in line with market prices would lead to fall in GDP or employment. Two, electricity consumption bears the burden of short run adjustment to reestablish the long run equilibrium.
\end{abstract}

Keywords: Equilibrium, electricity, consumption, electricity elasticety coefficieat, economic activity, south Asian countries, co-integration.

\section{Introduction}

South Asia is home to over one billion people. A majority of them are living without access to electricity. Modern technology is based on the availability of electricity. Electricity is an essential prerequisite not only for modern life but also to power machines to produce goods and services (Dhungel, 2003, Dhungel 2008a). Most of the South Asian countries obtain power from both nonrenewable sources such as nuclear, coal and natural gas and from renewable sources such as hydro, solar and wind power. Both of these sources to some extent are home-grown. All countries in the region are endowed with one source or another. Coal is available in India. Bangladesh and Pakistan are rich in natural gas, so is Nepal and Bhutan in hydropower. There is a golden opportunity to produce electricity from these indigenous sources. Among the potential sources, coal is highly exploited and has remained a major source of power for nearly a century and is expected to remain the same in the days to come. Hydro and natural gas remain untapped. They are yet to be exploited. These resources, if developed wisely, would be a boon for the development of South Asian countries (Dhungel, 2008b). It would provide ample opportunity for South Asian countries to exchange power with each other plugging a particular country's demand and supply gap. It would help to ensure energy security and provide scope for regional market integration. Also, almost all the countries have HEP potential, but to some extent the degree of availability varies. This represents a renewable source of energy. Obtaining a higher economic growth rate to the extent of it being in the double digits is the primary goal of the South Asian countries. However, double digit growth rate requires huge units of electricity. Presently, this is constrained by inadequate power supply. Thus, the goal is conditional upon an adequate and uninterrupted power supply. Electricity consumption and economic growth are closely interrelated. This paper aims to investigate the causal relationship between economic growth and electricity consumption in five countries of the region.

\section{Hydropower Potential}

Like coal and natural gas, the region possesses immense hydropower potential to the extent of 103 TWh which comprises $1.5 \%$ of global total. South Asian region is fortunate to have such vast potential because hydropower is renewable and non-polluting source of energy. Currently the region has only harnessed $28 \mathrm{GW}$ (Table 1). Despite the potential, the region depends on petroleum products from gulf counties in order to achieve targeted economic growth. In the process, there are intangible costs of pollution stimulating climate change. In this perspective, the benefit of the exploitation of hydropower is manifold. It facilitates to;

i) utilize region's untapped resources,

ii) ensure energy security,

iii) hold energy trade across the regional countries,

iv) create environment to integrate regional market,

v) reduce import bill of petroleum product, 
vi) Reduce greenhouse gas emission in the atmosphere.

\begin{tabular}{|l|c|c|c|}
\hline Potential & South Asia & Global & $\begin{array}{l}\text { Percent of } \\
\text { global total }\end{array}$ \\
\hline Theoretical & 3635 & 40784 & 8.9 \\
\hline Technical & 948 & 13945 & 6.8 \\
\hline Economic & 103 & 6964 & 1.5 \\
\hline Installed (gigawatts) & 28 & 655 & 4.3 \\
\hline
\end{tabular}

Source: World Energy Assessment 2000, UNDP. Table 1: Hydropower Potential in South Asia in TWh.

\section{Electricity Production}

Five countries of South Asia produce electricity amounted to 1374.693 billion KWh in 2011. Coal is the major source of electricity. It contributes more than $52 \%$ to total electricity production. The share of hydro, natural gas and renewable in electricity production is $12.22 \%, 12.83 \%$ and $16.03 \%$ respectively. India alone produces $86.1 \%$ of total followed by Pakistan (9.01\%), Bangladesh (3.1\%), Sri Lanka (1.2\%) and Nepal (o.48\%). Source: http:// www.nationmaster.com/index.php.

\section{Methodology \\ Data and Variables}

The study period depends primarily on the availability of data for all the selected five south Asian countries -Bangladesh, India, Nepal, Pakistan and Sri Lanka. For data processing purposes, these countries are numbered by $1,2,3,4$, and 5 respectively. On the basis of the availability of annual time series data for all the countries under consideration this study covers the time period from 2000 to 2011. Gross domestic product (GDP) and electricity consumption (EC) are the variables included in the study. Annual data of per capita GDP in PPP US dollar and EC in per capita KWh are obtained from Key Development Indicators and World Development Indicators of Asian Development Bank and the World Bank respectively and then they are expressed in logarithm. The average values of both the variables are plotted in figure 1.The distribution of the pair match observations have a trend with long run positive movement. It is observed that GDP growth is thinly associated with the electricity use in Nepal over the years as compared to the rest of the countries under consideration.

\begin{tabular}{|l|c|c|c|c|c|c|c|c|c|c|}
\hline \multirow{2}{*}{ Source } & \multicolumn{2}{|c|}{ Bangladesh } & \multicolumn{2}{c|}{ India } & \multicolumn{2}{c|}{ Nepal } & \multicolumn{2}{c|}{ Pakistan } & \multicolumn{2}{c|}{ Sri Lanka } \\
\cline { 2 - 14 } & Value & Percent & Value & Percent & Value & Percent & Value & Percent & value & Percent \\
\hline Coal & 0.78 & 0.06 & 714.95 & 52 & 0 & 0 & 0.096 & 0.007 & 1.04 & 0.08 \\
\hline Hydro & 0.872 & 0.06 & 130.67 & 9.51 & 3.31 & 0.24 & 28.52 & 2.07 & 4.62 & 0.34 \\
\hline Natural gas & 40.31 & 2.93 & 108.53 & 7.89 & 0 & 0 & 27.65 & 2.01 & 0 & 0 \\
\hline Nuclear & 0 & 0 & 33.29 & 2.42 & 0 & 0 & 5.26 & 0.38 & 0 & 0 \\
\hline Oil & 2.1 & 0.15 & 12.22 & 0.89 & 0.003 & 0 & 33.73 & 2.45 & 5.85 & 0.43 \\
\hline Renewable & 0.872 & 0.06 & 183.33 & 13.3 & 3.31 & 0.24 & 28.62 & 2.08 & 4.76 & 0.35 \\
\hline Total & 44.934 & 3.21 & 1182.99 & 86.1 & 6.623 & 0.48 & 123.9 & 9.01 & 16.27 & 1.2 \\
\hline
\end{tabular}

Table 2: Source wise electricity production in billion $\mathrm{KWh}$ in 2011

\section{Development Indicator}

Electricity is the major source of power. The nation's economic activities depends on its availability. Per capita electricity consumption, in the modern usage is taken as one of the measuring rods of development. Higher per capita electricity consumption shows a better development of a nation. The per capita electricity consumption of selected countries is given in Table 3. India's highest per capita electricity consumption $(684.11 \mathrm{KWh})$ indicates that it is a relatively more developed country in the South Asian region. The second highest is Sri Lanka with per capita electricity consumption (490.25 KWh) followed by Pakistan (449.25 KWh), Bangladesh (258.62 KWh) and Nepal (105.5 KWh). Source: (http://www.nationmaster.com/country-info/stats/ Energy/Electric-power-consumption/KWh-percapita.

\begin{tabular}{|l|l|l|l|l|l|}
\hline & Bangladesh & India & Nepal & Pakistan & Sri Lanka \\
\hline $\begin{array}{l}\text { Electricity } \\
\text { consumption }\end{array}$ & 258.62 & 684.11 & 105.5 & 449.25 & 490.25 \\
\hline
\end{tabular}

Table 3: Per capita electricity consumption in 2011(KWh/annum)

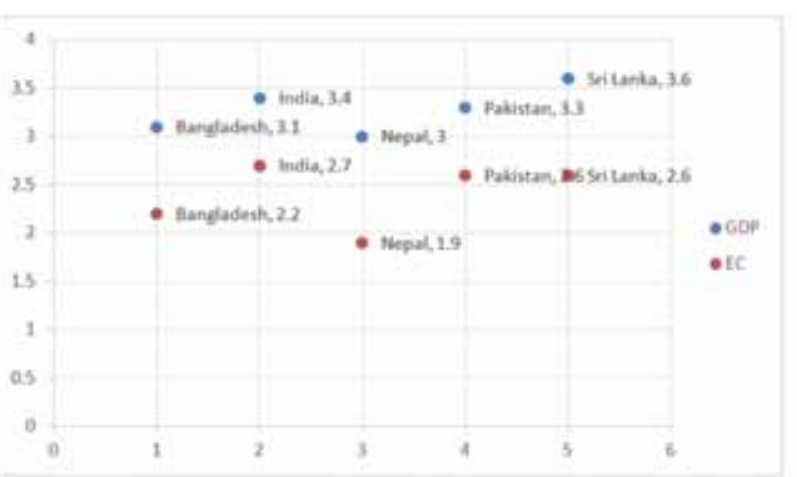

Figure 1: Graphical view of the mean value of GDP and EC

\section{Theoretical Structure}

Traditional production function models do not consider energy (electricity) as an input to produce output. Knife edge growth theory of Harrod-Domer and Solow Swan growth models claim that energy has no significant role in the production function. 
manual labor require electricity for their operation. Thus, in this sense, energy is the primary factor of production. The output is the result of the combined effort of labor, capital and energy. A number of studies such as Sharma and Dhakal (1994), Nourzad (2000), Paual and Bhattacharya(2004), Beaudreau (2005), Lee (2005), Thompson (2006), Dhungel (2014) and Sari and Soytas (2007) have shown strong evidence of internalization of the role of technology in the production function. Thus, in this respect their argument seems justifiable to internalize the role of energy in the production function.

\begin{tabular}{|l|c|c|}
\hline \multirow{2}{*}{\multicolumn{1}{|c|}{ Method }} & \multicolumn{2}{c|}{ Ge } \\
\cline { 2 - 3 } & \multicolumn{2}{c|}{ Level } \\
\cline { 2 - 3 } & Stat & Prob \\
\hline Levin, Lin \& Chu t* & 0.15473 & 0.5615 \\
\hline $\begin{array}{l}\text { Im, Pesaran and } \\
\text { Shin W-stat }\end{array}$ & 2.73337 & 0.9969 \\
\hline $\begin{array}{l}\text { ADF - Fisher Chi- } \\
\text { square }\end{array}$ & 2.77183 & 0.9863 \\
\hline $\begin{array}{l}\text { PP - Fisher Chi- } \\
\text { square }\end{array}$ & 1.08232 & 0.9998 \\
\hline
\end{tabular}

\section{The Model}

The present study aims to establish the relationship between GDP and EC by using Pedroni (2000), Fully Modified Ordinary Least Square (FMOLS) method and thereby investigate the Granger causality. FMOLS corrects biases of estimators with fixed effects arising from the problems of autocorrelation and heteroscedasticity and allows considerable heterogeneity among the individual cross sections Lee and Chang (2007). It considers possible correlation between the differences in constant term, dependent variables and error term. For this purpose, following type of equation is used to determine the relationship between the variables under consideration.

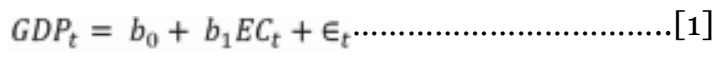

Where, $G D P_{t}=$ Per capita Gross domestic product at PPP dollars,

$E C_{t}=$ Per capita electricity consumption in KWh,

$E_{\mathrm{t}}=$ error term and

$b_{o}$ and $b_{1}$ are the parameters to be estimated.

In order to apply, FMOLS to estimate equation (1), there are some pertinent issues to be addressed. Investigation of panel co-integration is a must. Co-integration requires panel unit root test that can determine either the series are stationary or non-stationary. Thus, in this respect, this study investigates the panel unit root test and cointegration test before applying the FOMLS to establish the inter relationship between GDP and EC. Four methods (Levin, Lin \& Chu (2002), Im, Pesaran and Shin W-stat (2003) ADF - Fisher Chi-square and PP - Fisher Chi-square) are employed to determine the panel unit root in the series. Pedroni (2004) and Kao (1999) panel co-integration test methods are used to investigate the long run relationship between the variables under consideration.

Finally, Block Exogeneity Wald test based on VAR is applied to determine the causal relationship between the variables. If unidirectional causality runs from EC to GDP reduction of electricity consumption through bringing domestic energy prices in line with market prices would lead to fall in GDP or employment. On the other hand, if unidirectional causality runs from GDP to EC energy conservation policy such as phasing out energy subsidies or elimination of energy price distortions

\begin{tabular}{|c|c|c|c|c|c|}
\hline \multicolumn{2}{|l|}{} & \multicolumn{4}{|c|}{ EC } \\
\hline \multicolumn{1}{|c|}{ First Difference } & \multicolumn{2}{|c|}{ Level } & First Difference \\
\hline Stat & Prob & Stat & Prob & Stat & Prob \\
\hline$-4.25194^{*}$ & 0.0000 & 1.19115 & 0.8832 & $-5.17742^{*}$ & 0.0000 \\
\hline $22.2478 *$ & 0.0139 & 3.12672 & 0.9783 & $29.5989^{*}$ & 0.0010 \\
\hline $27.2810^{*}$ & 0.0082 & 2.53013 & 0.9943 & $-3.54111^{*}$ & 0.0002 \\
\hline
\end{tabular}

$\left(^{*}\right)$ significant at $1 \%$ level

have little adverse or no effects on economic growth (Abdoli et al. 2015, Bayer and Ozel, 2014).

\section{Empirical Finding}

\section{Unit Root Test}

Four types of test statistic (Table 4) were chosen to test the null hypothesis of unit root or $\mathrm{I}(\mathrm{o})$ in the variables GDP and EC. Lags are chosen automatically. These tests at level accept the null hypothesis of unit root. It means both the variables GDP and EC contain unit root indicating non-stationary in the data. But they become stationary at first difference in all the chosen test method. It indicates that they are in the same order I(1). It is the precondition to conduct panel co-integration test which determines the long run relationship between variables under consideration.

\section{Panel Co-integration Test}

The unit root test fulfills the precondition of no unit root in the series to conduct panel co-integration test between the variable GDP and EC. Under this test, no co-integration within the variables GDP and EC is the null hypothesis. There are eleven test outcomes of which eight are within dimension and the rest are between dimensions. Eight test outcomes are statistically significant at $5 \%$ level (Table 5). It indicates that the null hypothesis of no co-integration is rejected through the majority test outcomes and ensures that the variables are co-integrated. In the similar fashion, Kao residual test of co-integration also confirms that the variables are co-integrated. These evidences prove that the variables GDP and EC have long run equilibrium relationship.

\section{FMOLS Estimation}

The estimation results of FMOLS are presented 
in Table 6. The electricity elasticity coefficient (EEC) is 1.31 which is greater than 1 in panel FMOLS estimation. It implies that the demand for electricity is elastic and indicates that electricity consumption has positive impact on economic growth. A $1 \%$ increase in EC led to $1.31 \%$ increase in GDP. The implication is that economies of South Asian countries will grow at a faster rate if they supply adequate units of electricity. The same is true for individual countries. The EEC is greater than 1 except for Bangladesh, which ranges from 0.81 in Bangladesh to 1.69 in Pakistan. All the respective coefficients are statistically significant revealing that a $1 \%$ increase in electricity consumption would lead to increase the GDP by $0.81 \%, 1.51 \%, 1.10 \%, 1.69 \%$ and $1.53 \%$ in Bangladesh, India, Nepal, Pakistan and Sri Lanka respectively.

\begin{tabular}{|l|l|l|l|l|}
\hline \multirow{2}{*}{ Method } & \multicolumn{5}{c|}{ Pedroni within dimension } \\
\cline { 2 - 5 } & t-stat & Prob & $\begin{array}{l}\text { Weighted } \\
\text { t-stat }\end{array}$ & Prob \\
\hline Panel V-stat & $3.4231^{*}$ & 0.0085 & $3.6041^{*}$ & 0.0002 \\
\hline Panel rho-stat & $-3.8650^{*}$ & 0.0003 & $-2.3446^{*}$ & 0.0006 \\
\hline Panel PP-stat & $-1.9424^{*}$ & 0.0260 & $-1.9833^{*}$ & 0.0346 \\
\hline Panel ADF-stat & $-1.9402^{*}$ & 0.0262 & -1.2817 & 0.0536 \\
\hline & Pedroni between dimension & \\
\hline Group rho-stat & 0.6494 & 0.7420 & & \\
\hline Group PP-stat & $-2.8812^{*}$ & 0.0022 & & \\
\hline Group ADF-stat & -1.1673 & 0.1215 & & \\
\hline & Kao residual & & \\
\hline ADF & $-1.938326^{*}$ & 0.0263 & & \\
\hline
\end{tabular}

(*) significant at $5 \%$ level

Table 5: Results of panel co-integration test

\begin{tabular}{|l|c|c|c|c|}
\hline \multirow{2}{*}{ Countries } & \multicolumn{4}{|c|}{ EC is independent variable } \\
\cline { 2 - 5 } & Coefficient & Standard error & t-stat & Prob \\
\hline Panel & 1.31 & 0.072228 & $18.21097^{*}$ & 0.0000 \\
\hline Bangladesh & 0.81 & 0.063137 & $12.84932^{*}$ & 0.0001 \\
\hline India & 1.51 & 0.076244 & $19.76911^{*}$ & 0.0000 \\
\hline Nepal & 1.10 & 0.081592 & $12.84862^{*}$ & 0.0001 \\
\hline Pakistan & 1.69 & 0.279670 & $6.001975^{*}$ & 0.0018 \\
\hline Sri Lanka & 1.53 & 0.189083 & $8.100650^{*}$ & 0.0005 \\
\hline
\end{tabular}

Table 6: Estimated results of FMOLS (GDP is dependent variable)

\section{Granger Causality}

\section{All Sample Countries}

The Granger Causality based on the Vector Auto Regression for all the countries under consideration shows that the causality running from electricity consumption to Gross Domestic Product or EC to GDP. The value of Chi-square is 9.344 with probability
0.0094 which is significant at $5 \%$ level (Table 7). It rejects the null hypothesis: EC does not cause GDP. The implication is that the causality is running from EC to GDP. Theory suggests that if causality is running from electricity consumption to income, the shortage of electricity may negatively affect GDP. It implies that these countries are struggling with the shortage of electricity on the one and their economic development is highly dependent on the adequate availability of electricity on the other. It implies that all countries included in the analysis are suffering from the shortage of electricity. Shortage of electricity negatively affects the GDP growth. Thus they should place hard effort to generate electricity from the region's indigenous source.

\section{Individual Country}

The statistically significant coefficients of Chi-square test statistic (Table 7) reject the null hypothesis: EC does not cause GDP. It implies that the unidirectional causality is running from EC to GDP for Bangladesh, India and Nepal. It indicates that these economies are electricity dependent. Pakistan is just opposite. The statistically significant coefficients of Chi-square test statistic rejects the null hypothesis: GDP does not cause EC. It implies that the causality is running from GDP to EC. It implies that the economy of Pakistan is less dependent on electricity. It suggests that energy conservation policy may be implemented with little adverse or no effect on GDP. The estimated results for Sri Lanka is unique. There is bidirectional causality between EC and GDP. It implies that there is feedback effect on the economy.

\begin{tabular}{|l|l|l|l|c|}
\hline \multirow{2}{*}{ Country } & \multicolumn{4}{|c|}{ Regression on } \\
\cline { 2 - 5 } & \multicolumn{1}{|c|}{ (EC causing GDP) } & \multicolumn{1}{c|}{ (GDP causing EC) } \\
\cline { 2 - 5 } & Chi-square & Prob & Chi-square & Prob \\
\hline Panel & $9.343684^{*}$ & 0.0094 & 1.0555 & 0.5899 \\
\hline Bangladesh & $16.46118^{*}$ & 0.0003 & 4.463314 & 0.1073 \\
\hline India & $21.01098^{*}$ & 0.0000 & 1.224171 & 0.5222 \\
\hline Nepal & $15.43043^{*}$ & 0.0004 & 5.179362 & 0.0750 \\
\hline Pakistan & 1.464394 & 0.4001 & $15.42777^{*}$ & 0.0004 \\
\hline Sri Lanka & $8.727284^{*}$ & $0-0000$ & $10.07727^{*}$ & 0.0005 \\
\hline & \multicolumn{4}{|c}{$\left.{ }^{*}\right)$ significant at 1\% level } \\
Table 7: Results of VAR Granger causality,/Block Exogeneity \\
Wald test \\
Conclusions and Policy Implication \\
The exact relationship between electricity
\end{tabular}
consumption and economic activity can be assessed using model based either on demand side or on supply side. Considering electricity as an essential factor of production, this paper has used demand side model to reexamine the association and to determine the causality between the variables EC and GDP of five south Asian countries during the period 2000-2011. A panel unit root test and panel co-integration test are used to determine the long run equilibrium. Fully modified ordinary least square method was applied to estimate the panel electricity elasticity coefficient. Granger causality based on Vector Auto Regression 
model was then applied to determine the direction of causality.

The data were found to be stationary at first difference but were non-stationary at their level. Cointegration test confirmed the long run relationship or equilibrium between the variables EC and GDP. The electricity elasticity coefficient is 1.31 meaning that a $1 \%$ increase in electricity consumption would lead to increase in the GDP by $1.31 \%$. Electricity consumption is found to Granger cause GDP. This unidirectional causality running from electricity consumption to GDP has important policy implication. Electricity consumption leads to economic growth which has two policy outcomes. One, reduction of electricity consumption by bringing domestic energy prices in line with market prices that would lead to fall in GDP or employment. Two, electricity consumption bears the burden of short run adjustment to reestablish the long run equilibrium. Thus, in this connection, it can be concluded that energy conservation policy may harm economic growth in the south Asian countries. Hence, in general, electricity is an important ingredient for economic growth. In order to meet this requirement, it is necessary to place efforts to generate electricity from their untapped resources.

Kamal Raj Dhungel is Professor at Tribhuvan University, Nepal. He also earned his PhD from Tribhuvan University in 2008 for his thesis on "Trends and Patterns of Energy Consumption in Nepal". Prof. Dhungel has written more than a dozen academic books on the topics of energy and the economy in Nepal. Among those titles: Readings in Nepalese Economy, A Hand Book of Cost Benefit Analysis; Energy Issues in Nepal: A Macro Level Analysis; and Investment Prospects and Challenges for Hydropower Development in Nepal. He also serves on the editorial boards of several international journals, including the Platinum Global Journal of Social Science and Humanity (PGJSSH) and the International Journal of Econometrics and Financial Management.

\section{Footnote}

1. This paper is presented on the seminar Imagining South Asia in 2030: Emerging Trends, Challenges and Alternatives, 1-3 March 2016 at Pondichery University, India.

\section{References}

Abdoli, G., Farahani, Y.G. and Daston, S.,(2015). Electricity consumption and economic growth in OPEC countries: a cointegrated panel analysis, OPEC Energy Review, Vol.39, issue 1, pp.1-16.

Bayer, Y. and Ozel, H.A., (2014). Electricity consumption and economic growth in emerging economies, Journal of Knowledge Management, Economics and Information Technology, vol.10, issue 4.

Beaudreau, B.C., (2005). Engineering and economic growth. Structural Change and Economic Dynamics
16, pp, 211-220.

Dhungel K.R.(2014), “ On the relationship between electricity consumption and selected macroeconomic variables: empirical evidence from Nepal" Modern Economy, 5(4), PP. 360-366.

Dhungel, K R (2008a). A Causal Relationship between Energy Consumption and Economic Growth in Nepal, Asia Pacific Development Journal, 15(1) June 2008, UNSCAP, pp. 137-148.

Dhungel, K R (2008b). Regional Energy Trade in South Asia: Problems and Prospects, South Asia Economic Journal, 9(1) (2008), SAGE Publications, New Delhi, India, pp. 173-193

Dhungel, K R (2003). Income and Price Elasticity of the Demand for Energy: A Macro-level Empirical Analysis, Pacific and Asia Journal of Energy 13(2), New Delhi, India, pp.73-84.

Im, K.S., Pesaran, M.H., and Shin, Y., (2003). Testing for unit roots in heterogeneous panels. Journal of Econometrics, vol 115, Issue 1115 , pp. 53-74

Kao, C., (1999). Spurious Regression and Residual-Based Tests for Co-integration in Panel Data. Journal of Econometrics, 90, pp. 1-44.

Lee,C.C.,(2005).Energy consumption and GDP in developing countries: a co-integrated panel analysis, Energy Economics 27, 415-427.

Lee,C.C. Chang C.P.,(2007). Energy consumption and economic growth in Asian countries: a comprehensive analysis using panel data, Resource and Energy Economics, 30, Elsevier, pp.50-65.

Levin, A., Lin, C.F. \& Chu, C-S. J., (2002). Unit Root Tests in Panel Data: Asymptotic and Finite Sample Properties. Journal of Econometrics, 108, pp. 1-22.

Nourzad, F., (2000). The productivity effect of government capital in developing and industrialized countries. Applied Economics 32, pp.1181-1187.

Paul, S., Bhattacharya, R.N., (2004). Causality between energy consumption and economic growth in India: a note on conflicting results, Energy Economics 26, 977-983.

Pedroni, P., (2000). Fully modified OLS for heterogeneous cointegrated panels, Advances in Econometrics 15, 93-130.

Pedroni, P., (2004). Panel co-integration: asymptotic and finite sample properties 0 f pooled time series tests with an application to the PPP hypothesis. Econometric theory, 20(3), pp. 597-625.

Pokrovski, V.N., (2003). Energy in the theory of production. Energy 28, pp.769-788.

Sari, R., Soytas, U., (2007). The growth of income and energy consumption in six developing countries. Energy Policy 35(2), pp.889-898.

Sharma, S.C., Dhakal, D., (1994). Causal analyses between exports and economic growth in developing countries, Applied Economics 26, pp.1145-1157.

Stern,D.I.,(1997).Limits to substitution and irreversibility in production and consumption: A neoclassical interpretation of ecological economics, Ecological Economics 21 (3), pp.197-215.

Thompson, H., (2006\}. The applied theory of energy substitution in production, Energy Economics 28 (4), pp. $410-425$. 